\title{
Progress in perceptual research: the case of prosopagnosia
}

\section{[version 1; peer review: 2 approved]}

\author{
Andrea Albonico, Jason Barton (D)
}

Human Vision and Eye Movement Laboratory, Departments of Medicine (Neurology), Ophthalmology and Visual Sciences, Psychology, University of British Columbia, Vancouver, Canada

V1 First published: 31 May 2019, 8(F1000 Faculty Rev):765

https://doi.org/10.12688/f1000research.18492.1

Latest published: 31 May 2019, 8(F1000 Faculty Rev):765

https://doi.org/10.12688/f1000research.18492.1

\section{Abstract}

Prosopagnosia is an impairment in the ability to recognize faces and can be acquired after a brain lesion or occur as a developmental variant. Studies of prosopagnosia make important contributions to our understanding of face processing and object recognition in the human visual system. We review four areas of advances in the study of this condition in recent years. First are issues surrounding the diagnosis of prosopagnosia, including the development and evaluation of newer tests and proposals for diagnostic criteria, especially for the developmental variant. Second are studies of the structural basis of prosopagnosia, including the application of more advanced neuroimaging techniques in studies of the developmental variant. Third are issues concerning the face specificity of the defect in prosopagnosia, namely whether other object processing is affected to some degree and in particular the status of visual word processing in light of recent predictions from the "many-to-many hypothesis". Finally, there have been recent rehabilitative trials of perceptual learning applied to larger groups of prosopagnosic subjects that show that face impairments are not immutable in this condition.

\section{Keywords}

face recognition, neuroimaging, diagnosis, rehabilitation, object recognition

\section{Open Peer Review}

Approval Status

1 2

version 1

31 May 2019

Faculty Reviews are review articles written by the prestigious Members of Faculty Opinions. The articles are commissioned and peer reviewed before publication to ensure that the final, published version is comprehensive and accessible. The reviewers who approved the final version are listed with their names and affiliations.

1. Galia Avidan, Ben-Gurion University of the Negev, Beer-Sheva, Israel

\section{Richard Cook, Birkbeck, University of} London, London, UK Any comments on the article can be found at the end of the article. 
Corresponding author: Jason Barton (jasonbarton@shaw.ca)

Author roles: Albonico A: Conceptualization, Methodology, Writing - Original Draft Preparation; Barton J: Conceptualization, Formal Analysis, Supervision, Writing - Review \& Editing

Competing interests: No competing interests were disclosed.

Grant information: This work was supported by the Natural Sciences and Engineering Research Council of Canada (RGPIN 319129) and Canada Research Chairs (950-228984).

The funders had no role in study design, data collection and analysis, decision to publish, or preparation of the manuscript.

Copyright: ( 2019 Albonico A and Barton J. This is an open access article distributed under the terms of the Creative Commons Attribution License, which permits unrestricted use, distribution, and reproduction in any medium, provided the original work is properly cited.

How to cite this article: Albonico A and Barton J. Progress in perceptual research: the case of prosopagnosia [version 1; peer review: 2 approved] F1000Research 2019, 8(F1000 Faculty Rev):765 https://doi.org/10.12688/f1000research.18492.1

First published: 31 May 2019, 8(F1000 Faculty Rev):765 https://doi.org/10.12688/f1000research.18492.1 
The face is a complex structure. It has a complicated threedimensional shape, a substantial degree of mobility, and structural constraints that make all faces fairly similar; all of these issues present challenges to a perceptual system. Nevertheless, perhaps because of the social importance of faces, humans have developed the ability to recognize faces rapidly and accurately and with seemingly little effort. Indeed, recent estimates are that the typical person can remember and recognize about 5000 faces $^{1}$.

However, for some people, face recognition is not so easy. Prosopagnosia is a condition marked by the loss of familiarity for faces and the consequent inability to identify people by their faces $^{2}$. Although prosopagnosic subjects frequently turn to other cues such as voice, hairstyle, or anomalous facial features, these strategies have their limitations; as a result, prosopagnosic subjects still often find social situations stressful, and recent work has shown that they can suffer from anxiety, depression, and social withdrawal ${ }^{3,4}$.

Studies of prosopagnosia have a time-honoured place in research on face recognition. Neuropsychological observations have played key roles in the development of cognitive models of face processing ${ }^{5}$ and pointed to the cerebral substrates of face recognition ${ }^{6,7}$. Even in an era when advances in face research are coming from psychophysics, functional neuroimaging, and primate neurophysiology, there are still important contributions from work on prosopagnosia. This has been spurred particularly by the recognition of a developmental variant ${ }^{8}$. Although acquired prosopagnosia is rare, developmental prosopagnosia appears to be more common but debate on its exact prevalence continues ${ }^{9}$. Nevertheless, the greater availability of developmental subjects has led to an increase in the number of prosopagnosic studies. In this review, we focus on four areas of recent progress in the fields of acquired and developmental prosopagnosia.

\section{The diagnosis of prosopagnosia}

Uniform definitions are a critical starting point for research into a condition. The core defects in prosopagnosia are the loss of familiarity for previously known faces and the inability to learn to recognize new faces. In the past, this was often shown by tests using famous faces or in case studies by demonstrations that the subject could not recognize friends or family members. However, it is difficult to derive uniform diagnostic criteria from such tests. Familiarity for famous faces is affected by the subject's age, culture, education, and interests, for example, and carefully matched controls are essential for interpreting the results of such tests. This has led to supplementation of famous face tests by the increasing use of tests that assess short-term familiarity. These show faces in a learning phase and then present these "target" faces along with new "distractor" faces in a test phase in which subjects are asked to indicate which were the faces they had learned. The most well-known examples are the Warrington Recognition Memory Test $^{10}$ and the Cambridge Face Memory Test $^{11}$, the latter of which has the desirable feature of testing recognition across changes in pose or lighting. Compared with tests that use famous or personally known faces, tests of short-term familiarity provide limited exposure and lack the semantic and perceptual richness of long experience but have the advantage of uniformity in the degree of learning and testing. For the Cambridge Face Memory Test, there has also been substantial normative work showing good internal consistency (Cronbach's alpha ranges from 0.83 to 0.89 ) and no effects of intelligence or the ethnic mix of faces in the subject's life experience. There is a very modest advantage for women but a more significant effect of age in that accuracy declines for those over the age of $50^{11-13}$. Also, versions of this test have been developed for use in children ${ }^{14}$.

There are many other tests of face processing and these were recently reviewed in detail and categorized ${ }^{15}$. Diagnostic tests can be divided into three main types: (a) tests of face perception, which can include detecting faces in arrays or discriminating or matching simultaneously seen faces; (b) tests of face recognition, such as the tests for short- and long-term familiarity which were discussed above; and (c) tests of face identification, which involve naming or providing other information learned about the person whose face is shown. Prosopagnosic subjects are impaired on both recognition and identification. Performance on tests of face perception can be used to differentiate between prosopagnosic subjects who have an apperceptive variant, in which there is an under-specification of facial structure by perceptual processing, or an associative or amnestic variant, in which the problem is not perception but the ability of perceptual information to access facial memories ${ }^{16}$. Examples of tests assessing face perception are the Benton Facial Recognition Test $^{17}$, the Cambridge Face Perception Test ${ }^{18}$, the Glasgow Face Matching Test ${ }^{19}$, and the Caledonian Face Test ${ }^{20}$. Tests of face imagery have also been used to clarify the status of facial memories and diagnose the amnestic variant ${ }^{21}$.

Self-report questionnaires are becoming more common tools in diagnosing prosopagnosia. They are quick and easy, do not require equipment, do not need to be done in person and hence can be used to screen a large number of subjects, even at a distance. Among those are the Kennerknecht 15-item questionnaire ${ }^{22}$, the 20-item Prosopagnosia Index ${ }^{23}$, and the Cambridge Face Memory Questionnaire ${ }^{24}$. A potential concern is that individuals may have only modest insight into their face recognition abilities $^{25,26}$, particularly children ${ }^{27}$, although some studies suggest that this might not be the case for adults using the Prosopagnosia Index ${ }^{28,29}$. This concern might account for the fact that questionnaires may have high reliability but only modest sensitivity and specificity for diagnosing prosopagnosia ${ }^{24}$. Because of these concerns, some have advocated that questionnaires always be supplemented by objective tests for diagnosis ${ }^{9,24,30}$.

Recent reviews have discussed how to incorporate these various instruments into a diagnostic approach. This may be less of an issue for acquired prosopagnosia, in which the combination of an appropriate lesion on imaging, the subject's awareness of a change in face recognition after lesion onset, and poor performance on an objective test of face recognition makes the diagnosis plausible. For developmental prosopagnosia, there are no definite structural or genetic markers at present and so its diagnosis still rests solely on behavioural tests. One review 
pointed out the wide variations between studies in the types of tests, the number of tests, and the statistical cutoffs used ${ }^{9}$. This creates variable confidence in the diagnosis and introduces heterogeneity that can confound comparisons across groups and studies, an obstacle to scientific progress. As a result, there have been proposals for more uniform diagnostic criteria ${ }^{9,31}$. These include (i) subjective difficulty recognizing faces in daily life; (ii) objectively impaired face recognition on at least two tests of face recognition and criteria of at least 2 standard deviations below control means; (iii) intact general perceptual and memory function; and (iv) exclusion of other disorders associated with impaired face recognition, such as autism spectrum disorders.

Although reaching a firm diagnosis of developmental prosopagnosia has its hurdles, a recent study using qualitative methods suggested that screening for it may be possible with a simple list of 16 "hallmark symptoms" from experiences in daily life, which anyone can review ${ }^{27}$. The utility and sensitivity of this approach need to be explored.

\section{The neural basis of prosopagnosia}

The older literature has shown that lesions of acquired prosop${\text { agnosia are } \text { bilateral }^{6,7} \text { or limited to the right hemisphere }}^{32,33}$, and reports of left-sided lesions alone are $\operatorname{rare}^{34-36}$. This is consistent with evidence from functional neuroimaging that face processing induces greater activation in the right hemisphere ${ }^{37}$. The areas involved are the ventral occipito-temporal and fusiform cortex or anterior temporal cortex or both. These anatomic variants may correspond to functional variants ${ }^{16}$. Individuals with occipito-temporal or fusiform lesions are more likely to have an apperceptive variant ${ }^{38}$, whereas those with anterior temporal lesions have an amnestic variant along with better perceptual function and more difficulty with face imagery ${ }^{39}$.

Although by definition subjects with developmental prosopagnosia do not have large visible lesions, the status of their face processing networks can be studied with more subtle neuroimaging techniques, including measures of cortical thickness, the degree of functional activation, and connectivity within the network. The results as they currently stand are not conclusive. There are two main views. One proposes that developmental prosopagnosia is marked by alterations in various regions of the face network, particularly the fusiform gyrus, changes such as reduced cortical thickness or density ${ }^{40,41}$, reduced face selectivity of their activation ${ }^{40,42-44}$, local white matter abnormalities on diffusion imaging ${ }^{45,46}$, or reduced feedforward connectivity from early visual to occipito-temporal cortex ${ }^{47}$. The second proposes a disconnection between posterior and anterior regions within the face network ${ }^{48,49}$ on the basis of observations of preserved activation of the fusiform and ventral occipito-temporal cortex by faces ${ }^{50-52}$ and abnormalities in long white matter tracts that link posterior and anterior temporal cortex ${ }^{53,54}$.

Comparisons with other developmental disorders might be informative. Researchers on dyslexia have suggested a model in which a general risk for cortical anomalies is modulated by other genetic and/or environmental factors that determine the location and extent of such anomalies ${ }^{55}$. The latter determines the specific syndrome and can explain the frequent co-association of developmental disorders. In this regard, we note recent observations of associations between congenital amusia and developmental prosopagnosia ${ }^{56,57}$. Along these lines, others have speculated that abnormal neural migration may be responsible for developmental prosopagnosia ${ }^{8}$.

Does developmental prosopagnosia have a genetic cause? Face recognition abilities show a high degree of heritability in the general population ${ }^{58,59}$, and early observations were that developmental prosopagnosia tended to run in families ${ }^{59-63}$, possibly with an autosomal dominant pattern of inheritance ${ }^{22,64}$. However, most neurodevelopmental disorders are polygenic combinations of allelic variants present in the normal population. Along these lines, a recent study of 24 subjects reported that common single-nucleotide polymorphisms in the oxytocin receptor gene are associated with developmental prosopagnosia ${ }^{65}$. These preliminary results require replication in larger samples.

\section{Is prosopagnosia only about faces?}

A long-standing controversy is whether the impaired recognition in prosopagnosia is face-specific or affects other object types. This has important theoretical implications for how object recognition is organized in the visual system. The distributed view suggests that object processing is performed by networks of visual regions, and that some of these regions are involved in the perception of several types of stimuli ${ }^{66-68}$. The modular view claims that different categories of objects-particularly faces - are processed by distinct dedicated cortical regions ${ }^{69-71}$.

Case studies of acquired prosopagnosia have produced mixed results; some reported normal recognition of exemplars of other objects $^{72-82}$ and others showed impairments ${ }^{80,81,83-88}$. A recent major review ${ }^{89}$ examined 238 cases of developmental prosopagnosia in the literature. The majority of subjects had evidence of impaired object recognition, although a smaller number had reasonable evidence that object recognition was intact, given that they had both good accuracy and normal reaction times on tests. Although the authors concluded that the frequent association of face and object impairments supported a shared mechanism for recognizing faces and other objects ${ }^{89}$, the challenge for any comprehensive explanation is to account for both frequent associations and occasional dissociations. One of the most useful aspects of this review was the collection of accompanying commentaries ${ }^{90-104}$, which suggested both various hypotheses to explain this fact and methodologic limitations in the currently available data that need to be addressed in future work to allow a more definitive set of conclusions to be drawn.

A particular object type deserves comment - namely, words. One of the difficulties in comparing faces and objects is that humans have a great deal of experience and expertise with faces but such expertise cannot be assumed for other object types. Take cars, for example. A recent study found that, as a group, subjects with developmental prosopagnosia tended to score low on the 
Cambridge Car Recognition Test but that individual scores ranged quite widely, from excellent to poor ${ }^{105}$. However, not everyone is a car expert and variable expertise could affect recognition performance. In another group of studies, when visual car recognition scores were adjusted for car expertise, as reflected by a subject's semantic knowledge about cars, subjects with both acquired and developmental prosopagnosia tended to perform worse than expected ${ }^{16,106,107}$.

In literate societies, visual words, in contrast to cars, are a category for which almost all subjects have considerable perceptual expertise. The "many-to-many hypothesis" proposes that face and visual word processing share and compete for neural resources in regions like the fusiform gyrus and that structural constraints cause visual words to be processed more on the left, in proximity to language processing, and faces secondarily to lateralize to the right ${ }^{108-111}$. Lateralization is incomplete, though, and functional imaging shows overlap between face- and word-activated voxels ${ }^{112}$. As a consequence, the hypothesis predicts that prosopagnosia from right lesions should be accompanied by mild reading deficits in the processing of words and that alexia from left lesions should be accompanied by mild face recognition problems ${ }^{108}$. Whereas one study of three subjects with acquired prosopagnosia did show mild word recognition deficits ${ }^{113}$, other studies of visual word processing in acquired prosopagnosia from right-sided lesions alone have not found impaired reading ${ }^{14,115}$ and the same is true for developmental prosopagnosia $a^{116-118}$. On the other hand, the type of processing that is performed on words and faces may differ by hemisphere. Although subjects with acquired prosopagnosia from right-sided lesions may read normally, they often have trouble recognizing handwriting or font ${ }^{119-121}$, and subjects with alexia may recognize face identity ${ }^{122}$ but have trouble with lip reading ${ }^{119,123,124}$.

\section{Can prosopagnosia be treated?}

Spontaneous resolution of acquired prosopagnosia is $\operatorname{rare}^{125-127}$, and developmental prosopagnosia is a lifelong disorder. Hence, means of improving face recognition skills in these populations are of clinical interest. But can it be done? Neuroimaging shows that face processing activates a widely distributed network, including occipito-temporal, superior temporal, anterior temporal, and inferior frontal regions in both hemispheres, though more on the right ${ }^{128}$. It is highly unlikely that acquired lesions will eliminate all components of this network; furthermore, some studies in developmental prosopagnosia continue to show activation of this network by faces ${ }^{50-52}$. The open question is whether surviving components of the face network in a given prosopagnosic subject have any capacity for functional reorganization or modulation that could allow face recognition to improve through a rehabilitative approach ${ }^{129}$.

Most work has focused on behavioural interventions, although there is one intriguing report of transient improvement of developmental prosopagnosia after intranasal inhalation of $\operatorname{oxytocin}^{130}$. These rehabilitative attempts have been reviewed in detail ${ }^{129,131,132}$. Approaches can be divided into compensatory strategies, which aim to achieve person recognition by circumventing the face processing impairment, and remediation, which aims to improve that impairment. In terms of the process targeted, they can also be divided into those that focus on enhancing mnemonic function, which has been used in a few case studies $^{133-135}$, and those that target perceptual function. As examples of the latter, a few older case studies attempted to enhance attention to facial features, though results on face recognition were variable ${ }^{134,136-138}$.

The most significant recent advances have been trials of perceptual learning in groups rather than single cases of prosopagnosia. In one study of 24 subjects with developmental prosopagnosia ${ }^{139}$, subjects learned over the course of 2 weeks to discriminate distances between facial features, namely the distance between the eyes and eyebrows or between the nose and the mouth. These "spatial relations" can be thought of as indices of the complex geometry of faces, and studies show that some people with prosopagnosia are impaired in perceiving them ${ }^{38}$. This trial found improved face perception (but only if the test faces had a similar frontal view) and some modest improvements in subjective reports of daily experience with faces. A second study of 10 subjects with acquired prosopagnosia ${ }^{132}$ used morphed faces to train subjects over the course of 11 weeks to perceive finer and finer differences in facial shape; at the same time, the study introduced irrelevant variations in the expression and viewpoint of the face. In these subjects, compared with a control condition, there was a $21 \%$ absolute increase in perceptual sensitivity to facial shape after training, which generalized over new views and expressions. Importantly, there was also a $10 \%$ increase for new faces on which subjects had not trained, indicating that subjects were acquiring new skills rather than just learning a set of faces. The effects of training were still evident 3 months later. Although some but not all subjects related anecdotes pointing to improved face recognition in daily life, future studies will require formal evaluation of real-life benefit before such methods are translated to the clinic.

These rehabilitative studies represent a starting point. Although neither training method represents a "cure", they provide evidence that face processing can be changed in prosopagnosia. They also suggest that there may be individual differences in training potential. Further work is required to determine whether the perceptual gains from learning can be augmented further by better training design or the use of adjunctive methods to promote plasticity during learning.

\section{Grant information}

This work was supported by the Natural Sciences and Engineering Research Council of Canada (RGPIN 319129) and Canada Research Chairs (950-228984).

The funders had no role in study design, data collection and analysis, decision to publish, or preparation of the manuscript. 
1. F Jenkins R, Dowsett AJ, Burton AM: How many faces do people know? Proc Biol Sci. 2018; 285(1888): pii: 20181319.

PubMed Abstract | Publisher Full Text | Free Full Text | F1000 Recommendation

2. Corrow SL, Dalrymple KA, Barton JJ: Prosopagnosia: current perspectives. Eye Brain. 2016; 8: 165-75.

PubMed Abstract | Publisher Full Text | Free Full Text

3. Yardley L, McDermott L, Pisarski S, et al:: Psychosocial consequences of developmental prosopagnosia: a problem of recognition. J Psychosom Res. 2008; 65(5): 445-51.

PubMed Abstract | Publisher Full Text

4. Dalrymple KA, Fletcher K, Corrow S, et al:: "A room full of strangers every day": the psychosocial impact of developmental prosopagnosia on children and their families. J Psychosom Res. 2014; 77(2): 144-50.

PubMed Abstract | Publisher Full Text | Free Full Text

5. Bruce V, Young A: Understanding face recognition. Br J Psychol. 1986; 77(Pt 3): 305-27.

PubMed Abstract | Publisher Full Text

6. Meadows JC: The anatomical basis of prosopagnosia. $J$ Neurol Neurosurg Psychiatry. 1974; 37(5): 489-501.

PubMed Abstract | Publisher Full Text | Free Full Text

7. Damasio AR, Damasio H, Van Hoesen GW: Prosopagnosia: anatomic basis and behavioral mechanisms. Neurology. 1982; 32(4): 331-41.

PubMed Abstract | Publisher Full Text

8. Susilo T, Duchaine B: Advances in developmental prosopagnosia research. Curr Opin Neurobiol. 2013; 23(3): 423-9.

PubMed Abstract | Publisher Full Text

9. Barton JJS, Corrow SL: The problem of being bad at faces. Neuropsychologia. 2016; 89: 119-24.

PubMed Abstract | Publisher Full Text | Free Full Text

10. Warrington EK: Recognition Memory Test:(Faces). Test Booklet 2a: Nfer-Nelson; 1984.

Reference Source

11. Duchaine B, Nakayama K: The Cambridge Face Memory Test: results for neurologically intact individuals and an investigation of its validity using inverted face stimuli and prosopagnosic participants. Neuropsychologia. 2006; 44(4): 576-85.

PubMed Abstract | Publisher Full Text

12. Bowles DC, McKone E, Dawel A, et al:: Diagnosing prosopagnosia: effects of ageing, sex, and participant-stimulus ethnic match on the Cambridge Face Memory Test and Cambridge Face Perception Test. Cogn Neuropsychol. 2009; 26(5): 423-55.

PubMed Abstract | Publisher Full Text

13. Herzmann G, Danthiir V, Schacht A, et al.: Toward a comprehensive test battery for face cognition: assessment of the tasks. Behav Res Methods. 2008; 40(3): $840-57$.

PubMed Abstract | Publisher Full Text

14. Croydon A, Pimperton H, Ewing L, et al.: The Cambridge Face Memory Test for Children (CFMT-C): a new tool for measuring face recognition skills in childhood. Neuropsychologia. 2014; 62: 60-7. PubMed Abstract | Publisher Full Text

15. F Robotham RJ, Starrfelt R: Tests of whole upright face processing in prosopagnosia: A literature review. Neuropsychologia. 2018; 121: 106-21. PubMed Abstract | Publisher Full Text | F1000 Recommendation

16. Davies-Thompson J, Pancaroglu R, Barton J: Acquired prosopagnosia: structural basis and processing impairments. Front Biosci (Elite Ed). 2014; 6: 159-74. PubMed Abstract | Publisher Full Text

17. Benton AL, van Allen MW: Impairment in Facial Recognition in Patients with Cerebral Disease. Cortex. 1968; 4(4): 344-358, IN1. Publisher Full Text

18. Duchaine B, Yovel G, Nakayama K: No global processing deficit in the Navon task in 14 developmental prosopagnosics. Soc Cogn Affect Neurosci. 2007; 2(2): 104-13.

PubMed Abstract | Publisher Full Text | Free Full Text

19. Burton AM, White D, McNeill A: The Glasgow Face Matching Test. Behav Res Methods. 2010; 42(1): 286-91.

PubMed Abstract | Publisher Full Text

20. Logan AJ, Wilkinson F, Wilson HR, et al.: The Caledonian face test: A new test of face discrimination. Vision Res. 2016; 119: 29-41.

PubMed Abstract | Publisher Full Text

21. Barton JJ, Cherkasova M: Face imagery and its relation to perception and covert recognition in prosopagnosia. Neurology. 2003; 61(2): 220-5. PubMed Abstract | Publisher Full Text

22. Kennerknecht I, Ho NY, Wong VC: Prevalence of hereditary prosopagnosia (HPA) in Hong Kong Chinese population. Am J Med Genet A. 2008; 146A(22) 2863-70.

PubMed Abstract | Publisher Full Text

23. Shah P, Gaule A, Sowden S, et al:: The 20-item prosopagnosia index (PI20): a self-report instrument for identifying developmental prosopagnosia. $R$ Soc
Open Sci. 2015; 2(6): 140343

PubMed Abstract | Publisher Full Text | Free Full Text

24. F Arizpe JM, Saad E, Douglas AO, et al.: Self-reported face recognition is highly valid, but alone is not highly discriminative of prosopagnosia-level performance on objective assessments. Behav Res Methods. 2019 PubMed Abstract | Publisher Full Text | Free Full Text | F1000 Recommendation

25. Bindemann M, Attard J, Johnston RA, et al.: Perceived ability and actual recognition accuracy for unfamiliar and famous faces. Cogent Psychol. 2014; 1(1): 735

Publisher Full Text

26. Palermo R, Rossion B, Rhodes G, et al:: Do people have insight into their face recognition abilities? Q J Exp Psychol (Hove). 2017; 70(2): 218-33. PubMed Abstract | Publisher Full Text

27. F Murray E, Hills PJ, Bennetts RJ, et al.: Identifying Hallmark Symptoms of Developmental Prosopagnosia for Non-Experts. Sci Rep. 2018; 8: 1690 Publisher Full Text | F1000 Recommendation

28. Shah P, Sowden S, Gaule A, et al: The 20 item prosopagnosia index (PI20): relationship with the Glasgow face-matching test. $R$ Soc Open Sci. 2015; 2(11): 150305.

PubMed Abstract | Publisher Full Text | Free Full Text

29. F Livingston LA, Shah P: People with and without prosopagnosia have insight into their face recognition ability. Q J Exp Psychol (Hove). 2018; 71(5): 1260-2. PubMed Abstract | Publisher Full Text | F1000 Recommendation

30. Duchaine B: Comment on prevalence of hereditary prosopagnosia (HPA) in Hong Kong Chinese population. Am J Med Genet A. 2008; 146A(22): 2860-2 PubMed Abstract | Publisher Full Text

31. Dalrymple KA, Palermo R: Guidelines for studying developmenta prosopagnosia in adults and children. Wiley Interdiscip Rev Cogn Sci. 2016; 7(1): 73-87.

PubMed Abstract | Publisher Full Text

32. De Renzi E: Prosopagnosia in two patients with CT scan evidence of damage confined to the right hemisphere. Neuropsychologia. 1986; 24(3): 385-9. PubMed Abstract | Publisher Full Text

33. Landis T, Cummings JL, Christen L, et al:: Are unilateral right posterior cerebra lesions sufficient to cause prosopagnosia? Clinical and radiological findings in six additional patients. Cortex. 1986; 22(2): 243-52.

PubMed Abstract | Publisher Full Text

34. Mattson AJ, Levin HS, Grafman J: A case of prosopagnosia following moderate closed head injury with left hemisphere focal lesion. Cortex. 2000; 36(1): 125-37.

PubMed Abstract | Publisher Full Text

35. Tzavaras A, Merienne L, Masure MC: [Prosopagnosia, amnesia and language disorders caused by left temporal lobe injury in a left-handed man]. Encephale. 1973; 62(4): 382-94

PubMed Abstract

36. Barton JJ: Prosopagnosia associated with a left occipitotemporal lesion. Neuropsychologia. 2008; 46(8): 2214-24. PubMed Abstract | Publisher Full Text

37. Kanwisher N, McDermott J, Chun MM: The fusiform face area: a module in human extrastriate cortex specialized for face perception. J Neurosci. 1997; 17(11): 4302-11.

PubMed Abstract | Publisher Full Text

38. Barton JJ, Press DZ, Keenan JP, et al.: Lesions of the fusiform face area impai perception of facial configuration in prosopagnosia. Neurology. 2002; 58(1): 71-8.

PubMed Abstract | Publisher Full Text

39. Barton JJ: Structure and function in acquired prosopagnosia: lessons from a series of 10 patients with brain damage. J Neuropsychol. 2008; 2(Pt 1): 197-225. PubMed Abstract | Publisher Full Text

40. Dinkelacker V, Grüter M, Klaver $\mathrm{P}$, et al:: Congenital prosopagnosia: multistage anatomical and functional deficits in face processing circuitry. $J$ Neurol. 2011; 258(5): 770-82.

PubMed Abstract | Publisher Full Text | Free Full Text

41. Garrido L, Furl N, Draganski B, et al:: Voxel-based morphometry reveals reduced grey matter volume in the temporal cortex of developmental prosopagnosics. Brain. 2009; 132(Pt 12): 3443-55.

PubMed Abstract | Publisher Full Text | Free Full Text

42. Hadjikhani N, de Gelder B: Neural basis of prosopagnosia: an fMRI study. Hum Brain Mapp. 2002; 16(3): 176-82.

PubMed Abstract | Publisher Full Text

43. F Jiahui G, Yang H, Duchaine B: Developmental prosopagnosics have widespread selectivity reductions across category-selective visual cortex. Proc Natl Acad Sci U S A. 2018; 115(28): E6418-E6427. Proc Natl Acad Sci U S A. 2018; 115(28): E6418-E6427.
PubMed Abstract | Publisher Full Text | Free Full Text | F1000 Recommendation

44. Furl N, Garrido L, Dolan RJ, et al:: Fusiform gyrus face selectivity relates to individual differences in facial recognition ability. J Cogn Neurosci. 2011; 23(7): 1723-40.

PubMed Abstract | Publisher Full Text | Free Full Text 
45. Gomez J, Pestilli F, Witthoft N, et al.: Functionally defined white matter reveals segregated pathways in human ventral temporal cortex associated with category-specific processing. Neuron. 2015; 85(1): 216-27. PubMed Abstract | Publisher Full Text | Free Full Text

46. Song S, Garrido L, Nagy Z, et al.: Local but not long-range microstructural differences of the ventral temporal cortex in developmental prosopagnosia. Neuropsychologia. 2015; 78: 195-206.

PubMed Abstract | Publisher Full Text | Free Full Text

47. Lohse M, Garrido L, Driver J, et al.: Effective Connectivity from Early Visual Cortex to Posterior Occipitotemporal Face Areas Supports Face Selectivity and Predicts Developmental Prosopagnosia. J. Neurosci. 2016; 36(13): 3821-8. PubMed Abstract | Publisher Full Text | Free Full Text

48. Avidan G, Behrmann M: Impairment of the face processing network in congenital prosopagnosia. Front Biosci (Elite Ed). 2014; 6: 236-57. PubMed Abstract | Publisher Full Text

49. F Rosenthal G, Tanzer M, Simony E, et al.: Altered topology of neural circuits in congenital prosopagnosia. eLife. 2017; 6: pii: e25069. PubMed Abstract | Publisher Full Text | Free Full Text | F1000 Recommendation

50. Hasson $U$, Avidan G, Deouell $L Y$, et al.: Face-selective activation in a congenital prosopagnosic subject. J Cogn Neurosci. 2003; 15(3): 419-31. PubMed Abstract | Publisher Full Text

51. Avidan G, Hasson U, Malach R, et al.: Detailed exploration of face-related processing in congenital prosopagnosia: 2 . Functional neuroimaging findings. $J$ Cogn Neurosci. 2005; 17(7): 1150-67. PubMed Abstract | Publisher Full Text

52. F Avidan G, Behrmann M: Functional MRI reveals compromised neura integrity of the face processing network in congenital prosopagnosia. Curr Biol. 2009; 19(13): 1146-50.

PubMed Abstract | Publisher Full Text | Free Full Text | F1000 Recommendation

53. Thomas C, Avidan G, Humphreys K, et al:: Reduced structural connectivity in ventral visual cortex in congenital prosopagnosia. Nat Neurosci. 2009; 12(1): 29-31.

PubMed Abstract | Publisher Full Text | Free Full Text

54. $\mathrm{F}$ Zhao $\mathrm{Y}$, Zhen $\mathrm{Z}$, Liu $\mathrm{X}$, et al:: The neural network for face recognition: Insights from an fMRI study on developmental prosopagnosia. Neurolmage. 2018; 169: 151-61.

PubMed Abstract | Publisher Full Text | F1000 Recommendation

55. Ramus F: Neurobiology of dyslexia: a reinterpretation of the data. Trends Neurosci. 2004; 27(12): 720-6.

PubMed Abstract | Publisher Full Text

56. Corrow SL, Stubbs JL, Schlaug G, et al:: Perception of musical pitch in developmental prosopagnosia. Neuropsychologia. 2019; 124: 87-97. PubMed Abstract | Publisher Full Text

57. Paquette S, Li HC, Corrow SL, et al.: Developmental Perceptual Impairments: Cases When Tone-Deafness and Prosopagnosia Co-occur. Front Hum Neurosci. 2018; 12: 438 .

PubMed Abstract | Publisher Full Text | Free Full Text

58. Wilmer JB, Germine L, Chabris CF, et al:: Human face recognition ability is specific and highly heritable. Proc Natl Acad Sci U S A. 2010; 107(11): 5238-41. PubMed Abstract | Publisher Full Text | Free Full Text

59. Zhu Q, Song Y, Hu S, et al:: Heritability of the specific cognitive ability of face perception. Curr Biol. 2010; 20(2): 137-42. PubMed Abstract | Publisher Full Text

60. Grüter T, Grüter M, Carbon CC: Neural and genetic foundations of face recognition and prosopagnosia. J Neuropsychol. 2008; 2(Pt 1): 79-97. PubMed Abstract | Publisher Full Text

61. Schmalzl L, Palermo R, Coltheart M: Cognitive heterogeneity in genetically based prosopagnosia: a family study. J Neuropsychol. 2008; 2(Pt 1): 99-117. PubMed Abstract | Publisher Full Text

62. Duchaine B, Germine L, Nakayama K: Family resemblance: ten family members with prosopagnosia and within-class object agnosia. Cogn Neuropsychol. 2007; 24(4): 419-30.

PubMed Abstract | Publisher Full Text

63. Lee $Y$, Duchaine B, Wilson HR, et al:: Three cases of developmental prosopagnosia from one family: detailed neuropsychological and psychophysical investigation of face processing. Cortex. 2010; 46(8): 949-64. PubMed Abstract | Publisher Full Text

64. Kennerknecht I, Grueter T, Welling B, et al.: First report of prevalence of nonsyndromic hereditary prosopagnosia (HPA). Am J Med Genet A. 2006; 140(15): 1617-22.

PubMed Abstract | Publisher Full Text

65. Cattaneo Z, Daini R, Malaspina M, et al.: Congenital prosopagnosia is associated with a genetic variation in the oxytocin receptor (OXTR) gene: An exploratory study. Neuroscience. 2016; 339: 162-73. PubMed Abstract | Publisher Full Text

66. Behrmann M, Plaut DC: A vision of graded hemispheric specialization. Ann NY Acad Sci. 2015; 1359: 30-46.

PubMed Abstract | Publisher Full Text

67. O'Toole AJ, Jiang F, Abdi H, et al.: Partially distributed representations of objects and faces in ventral temporal cortex. J Cogn Neurosci. 2005; 17(4): 580-90.

PubMed Abstract | Publisher Full Text
68. F Robinson AK, Plaut DC, Behrmann M: Word and face processing engage overlapping distributed networks: Evidence from RSVP and EEG investigations. J Exp Psychol Gen. 2017; 146(7): 943-61. PubMed Abstract | Publisher Full Text | F1000 Recommendation

69. F Kanwisher N: The Quest for the FFA and Where It Led. J Neurosci. 2017; 37(5): 1056-61.

PubMed Abstract | Publisher Full Text | Free Full Text | F1000 Recommendation

70. McKone E, Kanwisher N: 17 Does the Human Brain Process Objects of Expertise Like Faces? A Review of the Evidence. From monkey brain to human brain. 2005; 339.

Reference Source

71. McKone $\mathrm{E}$, Crookes K, Jeffery L, et al:: A critical review of the development of face recognition: experience is less important than previously believed. Cogn Neuropsychol. 2012; 29(1-2): 174-212.

PubMed Abstract | Publisher Full Tex

72. Busigny $\mathrm{T}$, Joubert $\mathrm{S}$, Felician $\mathrm{O}$, et al:: Holistic perception of the individual face is specific and necessary: evidence from an extensive case study of acquired prosopagnosia. Neuropsychologia. 2010; 48(14): 4057-92.

PubMed Abstract | Publisher Full Text

73. Farah MJ, Levinson KL, Klein KL: Face perception and within-category discrimination in prosopagnosia. Neuropsychologia. 1995; 33(6): 661-74. PubMed Abstract | Publisher Full Text

74. Susilo T, Yovel G, Barton JJ, et al:: Face perception is category-specific: evidence from normal body perception in acquired prosopagnosia. Cognition. 2013; 129(1): 88-94.

PubMed Abstract | Publisher Full Text

75. Rezlescu C, Pitcher D, Duchaine B: Acquired prosopagnosia with spared withinclass object recognition but impaired recognition of degraded basic-level objects. Cogn Neuropsychol. 2012; 29(4): 325-47.

PubMed Abstract | Publisher Full Text

76. Rezlescu C, Barton JJ, Pitcher D, et al.: Normal acquisition of expertise with greebles in two cases of acquired prosopagnosia. Proc Natl Acad Sci U S A. 2014; 111(14): 5123-8.

PubMed Abstract | Publisher Full Text | Free Full Text

77. Riddoch MJ, Johnston RA, Bracewell RM, et al:: Are faces special? A case of pure prosopagnosia. Cogn Neuropsychol. 2008; 25(1): 3-26.

PubMed Abstract | Publisher Full Text

78. McNeil JE, Warrington EK: Prosopagnosia: a face-specific disorder. Q J Exp Psychol A. 1993; 46(1): 1-10.

PubMed Abstract | Publisher Full Text

79. Farah MJ, Wilson KD, Drain HM, et al.: The inverted face inversion effect in prosopagnosia: evidence for mandatory, face-specific perceptual mechanisms. Vision Res. 1995; 35(14): 2089-93.

PubMed Abstract | Publisher Full Text

80. Henke K, Schweinberger SR, Grigo A, et al:: Specificity of face recognition: recognition of exemplars of non-face objects in prosopagnosia. Cortex. 1998; 34(2): 289-96

PubMed Abstract | Publisher Full Text

81. Barton JJ, Cherkasova MV, Press DZ, et al.: Perceptual functions in prosopagnosia. Perception. 2004; 33(8): 939-56.

PubMed Abstract | Publisher Full Text

82. F Schiltz C, Sorger B, Caldara R, et al.: Impaired face discrimination in acquired prosopagnosia is associated with abnormal response to individual faces in the right middle fusiform gyrus. Cereb Cortex. 2006; 16(4): 574-86. PubMed Abstract | Publisher Full Text | F1000 Recommendation

83. Bornstein B, Sroka H, Munitz H: Prosopagnosia with animal face agnosia. Cortex 1969; 5(2): 164-9.

PubMed Abstract | Publisher Full Text

84. De Haan EH, Campbell R: A fifteen year follow-up of a case of developmental prosopagnosia. Cortex. 1991; 27(4): 489-509.

PubMed Abstract | Publisher Full Text

85. Gauthier I, Behrmann M, Tarr MJ: Can face recognition really be dissociated from object recognition? J Cogn Neurosci. 1999; 11(4): 349-70. PubMed Abstract | Publisher Full Text

86. Gomori AJ, Hawryluk GA: Visual agnosia without alexia. Neurology. 1984; 34(7) 947-50.

PubMed Abstract | Publisher Full Text

87. Newcombe F: The processing of visual information in prosopagnosia and acquired dyslexia: Functional versus physiological interpretation. Research in psychology and medicine. 1979; 1: 315-22.

88. Bruyer R, Laterre C, Seron X, et al.: A case of prosopagnosia with some preserved covert remembrance of familiar faces. Brain Cogn. 1983; 2(3): 257-84. PubMed Abstract | Publisher Full Text

89. F Geskin J, Behrmann M: Congenital prosopagnosia without object agnosia? A literature review. Cogn Neuropsychol. 2018; 35(1-2): 4-54. PubMed Abstract | Publisher Full Text | F1000 Recommendation

90. Rossion B: Prosopdysgnosia? What could it tell us about the neural organization of face and object recognition? Cogn Neuropsychol. 2018; 35(1-2): 98-101.

PubMed Abstract | Publisher Full Text 
91. Starrfelt R, Robotham RJ: On the use of cognitive neuropsychological methods in developmental disorders. Cogn Neuropsychol. 2018; 35(1-2): 94-7. PubMed Abstract | Publisher Full Text

92. Barton JJS: Objects and faces, faces and objects .... Cogn Neuropsychol. 2018; 35(1-2): 90-3.

PubMed Abstract | Publisher Full Text

93. de Gelder B, Van den Stock J: Face specificity of developmental prosopagnosia, moving beyond the debate on face specificity. Cogn Neuropsychol. 2018; 35(1-2): 87-9.

PubMed Abstract | Publisher Full Text

94. Ramon M: The power of how-lessons learned from neuropsychology and face processing. Cogn Neuropsychol. 2018; 35(1-2): 83-6. PubMed Abstract | Publisher Full Text

95. Eimer M: What do associations and dissociations between face and object recognition abilities tell us about the domain-generality of face processing? Cogn Neuropsychol. 2018; 35(1-2): 80-2. PubMed Abstract | Publisher Full Text

96. Nestor A: Congenital prosopagnosia: Deficit diagnosis and beyond. Cogn Neuropsychol. 2018; 35(1-2): 78-9. PubMed Abstract | Publisher Full Text

97. Rosenthal G, Avidan G: A possible neuronal account for the behavioural heterogeneity in congenital prosopagnosia. Cogn Neuropsychol. 2018; 35(1-2): 74-7. PubMed Abstract | Publisher Full Text

98. Towler JR, Tree JJ: Commonly associated face and object recognition impairments have implications for the cognitive architecture. Cogn Neuropsychol. 2018; 35(1-2): 70-3.

PubMed Abstract | Publisher Full Text

99. Gerlach C, Lissau $\mathrm{CH}$, Hildebrandt NK: On defining and interpreting dissociations. Cogn Neuropsychol. 2018; 35(1-2): 66-9. PubMed Abstract | Publisher Full Text

100. Campbell A, Tanaka JW: Decoupling category level and perceptual similarity in congenital prosopagnosia. Cogn Neuropsychol. 2018; 35(1-2): 63-5. PubMed Abstract | Publisher Full Text

101. Gray KLH, Cook R: Should developmental prosopagnosia, developmental body agnosia, and developmental object agnosia be considered independent neurodevelopmental conditions? Cogn Neuropsychol. 2018; 35(1-2): 59-62. PubMed Abstract | Publisher Full Text

102. Garrido L, Duchaine B, DeGutis J: Association vs dissociation and setting appropriate criteria for object agnosia. Cogn Neuropsychol. 2018; 35(1-2): 55-8. PubMed Abstract | Publisher Full Text | Free Full Text

103. Behrmann M, Geskin J: Over time, the right results will emerge. Cogn Neuropsychol. 2018; 35(1-2): 102-11. PubMed Abstract | Publisher Full Text

104. Susilo T: The face specificity of lifelong prosopagnosia. Cogn Neuropsychol. 2018; 35(1-2): 1-3. PubMed Abstract | Publisher Full Text

105. F Gray KLH, Biotti F, Cook R: Evaluating object recognition ability in developmental prosopagnosia using the Cambridge Car Memory Test. Cogn Neuropsychol. 2019; 26: 1-8. PubMed Abstract | Publisher Full Text | F1000 Recommendation

106. Barton JJ, Hanif H, Ashraf S: Relating visual to verbal semantic knowledge: the evaluation of object recognition in prosopagnosia. Brain. 2009; 132(Pt 12) 3456-66.

PubMed Abstract | Publisher Full Text | Free Full Text

107. F Barton JJS, Albonico A, Susilo T, et al:: Object recognition in acquired and developmental prosopagnosia. Cogn Neuropsychol. 2019; 1-31. PubMed Abstract | Publisher Full Text | F1000 Recommendation

108. Behrmann M, Plaut DC: Distributed circuits, not circumscribed centers, mediate visual recognition. Trends Cogn Sci. 2013; 17(5): 210-9. PubMed Abstract | Publisher Full Text

109. Dundas EM, Plaut DC, Behrmann M: The joint development of hemispheric lateralization for words and faces. J Exp Psychol Gen. 2013; 142(2): 348-58. PubMed Abstract | Publisher Full Text | Free Full Text

110. Dehaene S, Pegado F, Braga LW, et al:: How learning to read changes the cortical networks for vision and language. Science. 2010; 330(6009): 1359-64. PubMed Abstract | Publisher Full Text

111. Plaut DC, Behrmann M: Complementary neural representations for faces and words: a computational exploration. Cogn Neuropsychol. 2011; 28(3-4): 251-75. PubMed Abstract | Publisher Full Text

112. Nestor A, Behrmann M, Plaut DC: The neural basis of visual word form processing: a multivariate investigation. Cereb Cortex. 2013; 23(7): 1673-84. PubMed Abstract | Publisher Full Text

113. F Behrmann M, Plaut DC: Bilateral hemispheric processing of words and faces: evidence from word impairments in prosopagnosia and face impairments in pure alexia. Cereb Cortex. 2014; 24(4): 1102-18. PubMed Abstract | Publisher Full Text | F1000 Recommendation

114. Susilo T, Wright $\mathrm{V}$, Tree JJ, et al:: Acquired prosopagnosia without word recognition deficits. Cogn Neuropsychol. 2015; 32(6): 321-39. PubMed Abstract | Publisher Full Text

115. Hills CS, Pancaroglu R, Duchaine B, et al.: Word and text processing in acquired prosopagnosia. Ann Neurol. 2015; 78(2): 258-71.

PubMed Abstract | Publisher Full Text

116. Rubino C, Corrow SL, Corrow JC, et al:: Word and text processing in developmental prosopagnosia. Cogn Neuropsychol. 2016; 33(5-6): 315-28. PubMed Abstract | Publisher Full Text

117. F Starrfelt R, Klargaard SK, Petersen A, et al:: Reading in developmental prosopagnosia: Evidence for a dissociation between word and face recognition. Neuropsychology. 2018; 32(2): 138-47.

PubMed Abstract | Publisher Full Text | F1000 Recommendation

118. F Burns EJ, Bennetts RJ, Bate $\mathrm{S}$, et al:: Intact word processing in developmental prosopagnosia. Sci Rep. 2017; 7(1): 1683.

PubMed Abstract | Publisher Full Text | Free Full Text | F1000 Recommendation

119. Campbell $R$, Landis $T$, Regard $M$ : Face recognition and lipreading. A neurological dissociation. Brain. 1986; 109(Pt 3): 509-21. PubMed Abstract | Publisher Full Text

120. Rentschler I, Treutwein B, Landis T: Dissociation of local and global processing in visual agnosia. Vision Res. 1994; 34(7): 963-71. PubMed Abstract | Publisher Full Text

121. Barton JJ, Sekunova A, Sheldon C, et al:: Reading words, seeing style: the neuropsychology of word, font and handwriting perception. Neuropsychologia. 2010; 48(13): 3868-77. PubMed Abstract | Publisher Full Tex

122. F Robotham RJ, Starrfelt R: Face and Word Recognition Can Be Selectively Affected by Brain Injury or Developmental Disorders. Front Psychol. 2017; 8: 1547. PubMed Abstract | Publisher Full Text | Free Full Text | F1000 Recommendation

123. Albonico A, Barton JJS: Face perception in pure alexia: Complementary contributions of the left fusiform gyrus to facial identity and facial speech processing. Cortex. 2017; 96: 59-72. PubMed Abstract | Publisher Full Tex

124. Campbell R, Garwood J, Franklin S, et al.: Neuropsychological studies of auditory-visual fusion illusions. Four case studies and their implications. Neuropsychologia. 1990; 28(8): 787-802. PubMled Abstract | Publisher Full Text

125. Glowic $\mathrm{C}$, Violon $\mathrm{A}$ : [A case of regressive prosopagnosia (author's transI)]. Acta Neurol Belg. 1981; 81(2): 86-97. PubMed Abstract

126. Hier DB, Mondlock J, Caplan LR: Behavioral abnormalities after right hemisphere stroke. Neurology. 1983; 33(3): 337-44. PubMed Abstract | Publisher Full Text

127. Lang N, Baudewig J, Kallenberg K, et al.: Transient prosopagnosia after ischemic stroke. Neurology. 2006; 66(6): 916. PubMed Abstract | Publisher Full Text

128. Haxby JV, Hoffman EA, Gobbini MI: The distributed human neural system for face perception. Trends Cogn Sci. 2000; 4(6): 223-33. PubMed Abstract | Publisher Full Text

129. DeGutis JM, Chiu C, Grosso ME, et al.: Face processing improvements in prosopagnosia: successes and failures over the last $\mathbf{5 0}$ years. Front Hum Neurosci. 2014; 8: 561 . PubMed Abstract | Publisher Full Text | Free Full Text

130. Bate S, Cook SJ, Duchaine B, et al.: Intranasal inhalation of oxytocin improves face processing in developmental prosopagnosia. Cortex. 2014; 50: 55-63. PubMed Abstract | Publisher Full Text

131. Bate $S$, Bennetts RJ: The rehabilitation of face recognition impairments: a critical review and future directions. Front Hum Neurosci. 2014; 8: 491. PubMed Abstract | Publisher Full Text | Free Full Text

132. Davies-Thompson J, Fletcher K, Hills C, et al:: Perceptual Learning of Faces: A Rehabilitative Study of Acquired Prosopagnosia. J Cogn Neurosci. 2017; 29(3): 573-91. PubMed Abstract | Publisher Full Text

133. Wilson BA: Rehabilitation of memory. New York: Guilford Publications; 1987. Reference Source

134. Polster MR, Rapcsak SZ: Representations in learning new faces: evidence from prosopagnosia. J Int Neuropsychol Soc. 1996; 2(3): 240-8. PubMed Abstract | Publisher Full Text

135. Francis R, Riddoch MJ, Humphreys GW: 'Who's that girl?: ' Prosopagnosia, person-based semantic disorder, and the reacquisition of face identification ability. Neuropsychol Rehabil. 2002; 12: 1-26. Publisher Full Text

136. Powell J, Letson S, Davidoff J, et al:: Enhancement of face recognition learning in patients with brain injury using three cognitive training procedures. Neuropsychol Rehabil. 2008; 18(2): 182-203. PubMed Abstract | Publisher Full Text

137. Mayer E, Rossion B, Godefroy O, et al:: The Behavioral Cognitive Neurology of Stroke. Cambridge University Press Cambridge; 2007. Reference Source

138. Beyn ES, Knyazeva GR: The problem of prosopagnosia. J Neurol Neurosurg Psychiatry. 1962; 25: 154-8. PubMed Abstract | Publisher Full Text | Free Full Text

139. DeGutis J, Cohan S, Nakayama K: Holistic face training enhances face processing in developmental prosopagnosia. Brain. 2014; 137(Pt 6): 1781-98. PubMed Abstract | Publisher Full Text | Free Full Text 


\section{Open Peer Review}

\section{Current Peer Review Status:}

\section{Editorial Note on the Review Process}

Faculty Reviews are review articles written by the prestigious Members of Faculty Opinions. The articles are commissioned and peer reviewed before publication to ensure that the final, published version is comprehensive and accessible. The reviewers who approved the final version are listed with their names and affiliations.

\section{The reviewers who approved this article are:}

\section{Version 1}

\section{Richard Cook}

Department of Psychological Sciences, Birkbeck, University of London, London, UK

Competing Interests: No competing interests were disclosed.

\section{Galia Avidan}

Department Psychology, Ben-Gurion University of the Negev, Beer-Sheva, Israel

Competing Interests: No competing interests were disclosed.

The benefits of publishing with F1000Research:

- Your article is published within days, with no editorial bias

- You can publish traditional articles, null/negative results, case reports, data notes and more

- The peer review process is transparent and collaborative

- Your article is indexed in PubMed after passing peer review

- Dedicated customer support at every stage

For pre-submission enquiries, contact research@f1000.com 